\title{
Pombal e o Império Atlântico: impactos políticos da criação do Erário Régio ${ }^{I}$
}

\author{
Miguel Dantas da Cruz[1]
}

\begin{abstract}
Resumo
A governação pombalina encerra um significado bastante consensual. Trata-se de um período marcado pela gradual concentração de faculdades decisórias no monarca e no grupo dirigente e pela introdução generalizada de dispositivos legislativos destinados a controlar a sociedade civil. Trata-se também do momento em que a administração de cariz corporativo, vigente em todos os territórios da monarquia, foi definitivamente suprimida. No entanto, os termos da consolidação do poder da Coroa, na segunda metade dos Setecentos, ainda que elencados amiúde, ficam frequentemente por esmiuçar. É necessário compreender ainda muitas das nuances envolvidas nessa transformação, nomeadamente no que toca às rotinas de governo. Este estudo revisita e discute a centralização política pombalina. Procura, em especial, aferir os contornos e as resistências ao processo desencadeado por Carvalho e Melo no quadro da coabitação do Erário Régio com as Juntas da Real Fazenda do Brasil, que, em conjunto, formaram uma das estruturas político-administrativas que melhor encapsulavam as ambições do ministro de D. José I.
\end{abstract}

Palavras-chave: Erário Régio; centralização política; Marquês de Pombal.

\section{Pombal y el Imperio Atlántico: impactos políticos de la creación de la Real Hacienda}

\section{Resumen}

El gobierno de Pombal tiene un significado bastante consensual. Es un período caracterizado por la progresiva concentración de facultades decisorias en el monarca y el grupo en el poder y por la introducción generalizada de las disposiciones legislativas para controlar la sociedad civil. Este también es el momento en que la administración de carácter corporativo, en vigor en todos los territorios de la monarquía, fue eliminada definitivamente. Sin embargo, los términos de la consolidación del poder de la Corona en la segunda mitad del siglo 18, aunque muchas veces enumerados, con frecuencia quedan por escudriñar. Es necesario comprender aún muchos de los matices implicados en esta transformación, particularmente con respecto a las rutinas del gobierno. Este estudio revisa y discute la centralización política de Pombal. También busca, en particular, evaluar los contornos y las resistencias al proceso desencadenadas por Carvalho y Melo bajo la cohabitación de la Real Hacienda con las Juntas de Real Hacienda de Brasil, que juntas formaron una de las estructuras político-administrativas que mejor contenían la ambiciones del Ministro de D. José I. Palabras clave: Real Hacienda; centralización política; Marqués de Pombal.

\section{Pombal and the Atlantic Empire: political impacts of the foundation of the Royal Treasury}

\section{Abstract}

The Pombaline government has a fairly consensual meaning. It encompasses a period marked by the gradual concentration of deciding faculties in the monarch and the leading ministers and by the general introduction of legislation designed to exert higher control over the civil society. It was also a time of cultural change as far as the political models were concerned. The corporative nature of the regime was definitely suppressed. However, the consolidation of power of the Crown in the second half of the 18th century is frequently left to be analyzed. There is still much to be learned about the particularities involved in this transformation, namely in regard to governing routines or practices. This study reexamines and discusses the centralization of the Pombaline politics. The study is especially concerned with the predicaments and resistances encountered by the process initiated by Carvalho e Melo. In order to meet this ambition I will address the coexistence of the Royal Treasury (Erário Régio) with the Boards of Royal Finance (Juntas da Real Fazenda) of Brazil, which together formed a cornerstone of the political reform and a gateway to the all-powerful minister intentions. Keywords: Royal Treasury; political centralization; Marquis of Pombal.

\section{Pombal et l'Empire Atlantique: répercussions politiques de la création du Trésor Royal}

\section{Résumé}

Le gouvernement de Pombal a une signification consensuelle. C'était une période marquée par la concentration de décisions au monarque et son groupe dirigeant et par l'introduction de dispositifs législatifs pour contrôler la société civile. Il a été aussi le moment oú ladministration de caractere corporatif, en vigueur dans le territoire monarque, a été supprimée définitivement. Cependant, les termes de la consolidation du pouvoir de la couronne, dans la seconde moitié des 1700, même souvent énumérés, se sont avérés insuffisants. Il est nécessaire en effet de comprendre dês nombreuses nuances inhérentes à la transformation, principalement en ce qui concerne les routines du government. Cette étude revisite et discute la centralization politique de Pombal. On s'efforce de définir les formes et les résistances au processus lancé par Carvalho et Melo en concernant la cohabitation du Trésor Royal avec le quartier de la Real Fazenda au Brésil, qui ont formé une des structures politico-administrative qui correspondaient plus à les ambitions du ministre D. José I.

Mots-clés: Trésor Royal; centralisation politique; Marquès de Pombal.

Artigo recebido em 16 de setembro de 2014 e aprovado para publicação em 13 de outubro de 2014

[1] Instituto de Ciências Sociais da Universidade de Lisboa - Lisboa - Portugal - E-mail: miguel.cruz@ics.ulisboa.pt

'A primeira versão deste texto foi apresentada no 310 Encontro da APHES - Economia e Instituições: perspectivas históricas, que ocorreu nos dias 19 e 20 de novembro de 2011, na Faculdade de Economia da Universidade de Coimbra. Gostaria de agradecer a Isabel Corrêa da Silva, a Rita Carvalho, colegas do ICS, ao Professor José Vicente Serrão e aos pareceristas da Revista Tempo pela leitura crítica da versão inicial deste trabalho. Gostaria também de agradecer as sugestões do Professor Nuno Gonçalo Monteiro. 
$\mathrm{E}$ ste estudo debruça-se sobre o processo de centralização política desencadeado na monarquia portuguesa, na segunda metade dos Setecentos, altura em que se terá assistido à gradual concentração de faculdades decisórias no monarca e no grupo dirigente e à generalizada implementação de mecanismos de dominação da sociedade civil. Não se furtando à discussão de um conceito historiográfico bastante controverso, ${ }^{2}$ este estudo se sustenta, sobretudo, numa investigação dedicada aos termos da convivência do Erário Régio com as Juntas da Real Fazenda do Brasil, que, em conjunto, formaram significativamente uma das estruturas político-administrativas que melhor encapsularam as ambições de Sebastião de Carvalho e Melo. ${ }^{3}$

O ministério pombalino constitui um tema incontornável da historiografia portuguesa e internacional. De resto, à imagem do que acontece a outras figuras ligadas ao despotismo esclarecido, existe uma longa tradição de trabalho dedicado ao principal governante do século XVIII português. Existe também muita controvérsia, desde a sua problemática inserção no movimento das Luzes, ${ }^{4}$ nas suas múltiplas variedades, ${ }^{5}$ ao estatuto formal da sua posição política (primeiroministro sem título), sem esquecer as referências norteadoras da sua ação política e econômica (dentre as quais ele próprio destacou os nomes de Sully e Richelieu). ${ }^{6}$

O Pombalismo correspondeu a um período de transição política da maior importância, mesmo quando, em debate paralelo, se prefere valorizar a preponderância histórica das Revoluções Liberais para o subsequente desenvolvimento do Estado como o conhecemos. ${ }^{7}$ Trata-se do momento em que o governo político, baseado numa "administração ativa", superou em definitivo a administração

${ }^{2} \mathrm{~A}$ questão não é meramente terminológica, mas foi, sobretudo, na forma que o tema se tornou mais polêmico. De fato, raramente alguém se apresenta com o objetivo de discutir os contornos da centralização política per se, tal como o fizeram autores como José Esteves Pereira. No entanto, as grelhas de análise utilizadas denunciam inquietações que estão efetivamente próximas. Ver José Esteves Pereira, "Teorização absolutista e centralização", In: ___...Percursos de história das ideias, Lisboa, INCM, 2004, p. 107-123.

${ }^{3} \mathrm{O}$ ritmo de criação das Juntas da Real Fazenda não foi particularmente rápido. A primeira a ser instalada foi em Goiás, em 1761, mas as últimas só foram estabelecidas na segunda década do século XIX.

${ }^{4} \mathrm{~A}$ inserção de Pombal no Movimento das Luzes tem-se revelado especialmente difícil. É certo que o ministro de D. José l legislou frequentementeem conformidade com o espírito reformador da segunda metade dos Setecentos, porém não é menos verdade que, por vezes, resgatou práticas completamente ultrapassadas e já abandonadas por muitos governos europeus. Essas contradições foram especialmente bem explicadas por Ana Cristina Araújo, A Cultura das Luzes em Portugal - temas e problemas, Lisboa, Livros Horizonte, 2003. Por exemplo, a afirmação da política cultural pombalina, assente na criação da Diretoria Geral dos Estudos, na criação da Imprensa Régia e no estabelecimento de um programa nacional de educação (entre outras iniciativas), coabitou com supressão da imprensa periódica de vocação literária e filosófica que prosperou a partir de 1740. A esse respeito, ver também Kenneth Maxwell, "Pombal: the paradox of enlightenment and despotism", In: Hamish M. Scott, Enlightenment Absolutism. Reform and reformers in later eighteenth-century Europe, Londres, MacMillan, 1990, p. 75-118; Nuno Gonçalo Monteiro, "Pombal's government: between seventeenth-century valido and Enlightenment", In: Gabriel B. Paquette (org.), Enlightened reform in Southern Europe and its Atlantic colonies, c.1750-1830, Farnham, Ashgate, 2009; e, ainda, José Luís Cardoso; Alexandre Mendes Cunha, “Discurso econômico e política colonial no Império Luso-Brasileiro (1750-1808)", Tempo, vol. 16, n. 31, 2011, p. 65-88.

${ }^{5} \mathrm{~A}$ pesquisa realizada nas últimas décadas redefiniu o mapa conceitual do lluminismo. É hoje muito claro que este só pode ser corretamente interpretado à luz dos diferentes contextos geográficos e políticos. Entre muitos exemplos, ver: Jonathan Israel, Radical Enlightenment: Philosophy and the making of Modernity, 1650-1750, Notre Dame, The University of Notre Dame Press, 2001; Gertrude Himmelfarb. The roads to Modernity: the British, French and American Enlightenment, New York, Knopf, 2004; e Gabriel B. Paquette (org.), Enlightened reform in Southern Europe and its Atlantic colonies, c.1750-1830, Farnham, Ashgate, 2009. ${ }^{6}$ Nuno Gonçalo Monteiro, D. José - na sombra de Pombal, Lisboa, Temas e Debates, 2008, p. 293-304.

${ }^{7}$ Para o caso português, ver, por exemplo, Pedro Cardim, "Centralização política e Estado na recente historiografia sobre o Portugal do Antigo Regime", Nação e Defesa, n. 87, 1998, p. 129-158. 
de cariz corporativo vigente até esse momento. ${ }^{8}$ Daí em diante, fazer política já não correspondia somente ao exercício de funções judicativas majoritariamente orientadas para a manutenção da ordem das coisas. ${ }^{9} \mathrm{O}$ mais notável é que foram precisamente as instituições tradicionais, intrinsecamente avessas à mudança, que asseguraram o suporte indispensável à iniciativa de Carvalho e Melo, conforme sugeriu José Vicente Serrão. Em suas palavras, “o Pombalismo identifica-se com o Estado e serve-se dele no seu afã reformador, que procura abarcar todos os domínios da vida nacional". ${ }^{10}$ Não é por acaso que a ideia de um Iluminismo com "feição de Estado" permanece sedutora, ${ }^{11}$ pelo menos entre os historiadores que se sentem mais confortáveis em remeter Carvalho e Melo para aquele grande movimento europeu.

No entanto, convém sublinhar que, se a mudança pombalina parece evidente por si mesma e, por isso, é assumida sem grande relutância, a sua eficácia tem ficado frequentemente por esmiuçar. Os sinais da consolidação do poder da Coroa em múltiplos planos (jurisdicional, legislativo, fiscal, militar, entre outros), no Portugal de Carvalho e Melo, parecem de tal modo evidentes que a sua demonstração se tornou quase supérflua. Em regra, articulando a vasta reforma legislativa levada a cabo pelo principal ministro de D. José I com a concentração de poder na sua pessoa, assume-se (não sem alguma razão) que se tratou de uma conjuntura marcada pelo irresistível avanço das prescrições centralizadoras, emanadas por um governo incontestado. Contudo, salvo notáveis exceções, ${ }^{12}$ os parâmetros da centralização da política iniciada por Pombal e, sobretudo, a resistência com que ela se deparou nas rotinas governativas (durante e depois do seu consulado) permanecem arredados da agenda historiográfica, pelo menos enquanto objeto específico.

Têm faltado, por exemplo, abordagens que acompanhem de perto o funcionamento de algumas das estruturas fundadas na sequência do frenesi reformador de Carvalho e Melo e que são frequentemente elencadas sem aprofundamento adicional. A esse respeito, Damião Rodrigues, em artigo originalmente publicado na Revista Tempo, chamou a atenção para a necessidade de analisar as "discrepâncias entre as intenções e os resultados", "entre as ambições do legislador e os limites à implementação do projeto".13

\footnotetext{
8José Subtil, "Os poderes do centro", In: António Hespanha (coord.), História de Portugal: o Antigo Regime, vol. 4, Lisboa, Estampa, 1998, p. 143.

${ }^{9}$ Michel Senellart, Les arts de gouverner. Du régime médiéval au concept de gouvernement, Paris, Seuil, 1995 10 José Vicente Serrão, "Sistema político e funcionamento institucional", In: Fernando Marques da Costa; Francisco Contente Domingues; Nuno Gonçalo Monteiro (orgs.), Do Antigo Regime ao Liberalismo, Lisboa, Vega, 1989, p. 19. "Sobre essa perspectiva, ver Pedro Calafate, "Filosofia política", In:___. (dir.), História do pensamento filosófico português: as Luzes, vol. 3, Lisboa, Caminho, 2001, p. 45-62.

${ }^{12}$ Entre outros, ver: Carla M. J. Anastasia, "Lei da Boa Razão e o novo repertório da ação coletiva nas Minas setecentistas", Varia Historia, n. 28, 2002, p. 29-38; Joaquim Romero de Magalhães, "Um novo método de governo: Francisco Xavier de Mendonça Furtado, Governador e Capitão-General do Grão-Pará e Maranhão (1751-1759)", Revista do Instituto Histórico e Geográfico Brasileiro, vol. 165, n. 424, 2004, p. 183-209; e José Damião Rodrigues, "'Para o Socego e tranquilidade publica das Ilhas': fundamentos, ambição e limites das reformas pombalinas nos Açores", In: __... Histórias atlânticas: os Açores na primeira modernidade, 2. ed., Lisboa, CHAM, 2012, p. 205-228.

13/bidem, p. 211.
} 
É necessário compreender ainda muitas das nuances envolvidas nessa transformação, nomeadamente no que toca às rotinas do governo. Por exemplo, há que se saber se as medidas de Carvalho e Melo canalizaram para Lisboa a resolução de todas as matérias, ou se o avanço da intervenção governamental foi acompanhado por uma (provavelmente indispensável) delegação de poderes nas instâncias da administração periférica da Coroa, nomeadamente no caso ultramarino, que aqui nos interessa mais. A esse respeito, sobressai uma dúvida, raramente formulada e que se prende com os termos específicos da mudança administrativa: será que o impulso reformador de Pombal modificou fundamentalmente a relação de Lisboa com os poderes locais na América, restringindo a sua autonomia (o que correspondente ao conceito de centralização mais vulgar)? Ou será que esse impulso reformador correspondeu a um processo que deve ser considerado, sobretudo, ao nível da administração régia, isto é, no quadro da interação de órgãos centrais e de instituições relacionadas com administração periférica da coroa (e, nesse caso, talvez seja melhor falar de descentralização burocrática, por conta do reforço eventual de atribuições da periferia)?

\section{Naturalmente, essa autonomia camarária não recolhia (provavelmente nunca recolheu) um consenso alargado e, a partir de 1711, começou a ser suprimida}

Essa tarefa - compreender o significado e a materialização das reformas políticas e institucionais promovidas por Pombal — apresenta, contudo, um grau de dificuldade assinalável, sendo particularmente difícil encontrar uma plataforma de diálogo historiográfico. É que a história política do império português, renovada por aproximações de pendor mais pós-estruturalista, rejeitou a ideia de Estado, ao mesmo tempo que deitou fora a ideia de centralização política, o que não deixa de ser uma opção questionável. Pelo menos, esse é o entendimento de historiadores como Laura de Mello e Souza, ${ }^{14}$ especialmente renitente quanto à aplicação dessa abordagem ao Brasil dos Setecentos, ou Diogo Ramada Curto, que, na esteira de Christopher Bayly, chamou a atenção de forma mais genérica para a conveniência de resgatar o "Estado colonial com todos os seus limites como agente da história".15

Ainda que os graus de adesão sejam, portanto, variáveis, ${ }^{16}$ tal opção metodológica tem transformado a história da administração da América portuguesa na história da negociação permanente entre a Colônia e a Coroa distante. O enfoque

${ }^{14}$ Laura de Mello e Souza, O Sol e a Sombra: política e administração na América portuguesa do século XVIII, São Paulo, Companhia das Letras, 2006, p. 57.

${ }^{15}$ Diogo Ramada Curto, Cultura imperial e projetos coloniais (séculos XV a XVIII), Campinas, Editora da UNICAMP, 2009, p. 9, e Christopher Bayly, Origins of nationality in South Asia: patriotism and ethical government in the making of modern India, Nova Deli, Oxford University Press, 1998.

${ }^{16}$ Existem vários autores que rejeitam a ideia de uma monarquia quase acéfala, em que a coroa representava apenas mais um poder. Dentre eles, destaco ainda Fernanda Olival, "Mercês, serviços e circuitos documentais no Império Português", In: Maria Emília Madeira dos Santos; Manuel Lobato (orgs.), O domínio da distância comunicação e cartografia, Lisboa, IICT, 2006, p. 59-71. 
mais ou menos deliberado nas dinâmicas de continuidade (sobretudo no que diz respeito aos aspectos sociais da colonização) dificulta a identificação das grandes transformações políticas e institucionais do ultramar português ou mesmo das roturas inseridas na política colonial (conceito que quase desapareceu do léxico historiográfico). Não é por acaso que se detectam divergências gritantes na avaliação que autores de reconhecida autoridade fazem sobre as cronologias e sobre os conteúdos da política atlântica dos Braganças. ${ }^{17}$

A esse respeito, é muito significativo o caso do Erário Régio e do sistema de Juntas da Administração da Real Fazenda ${ }^{18}$ que ele encimava, completamente submergido pelo domínio de uma perspectiva historiográfica que se debruça sobre o império em consonância com outras prioridades. Nesse sentido, não espanta que saibamos tão pouco acerca do seu funcionamento e sobre a forma como este veiculava uma nova política colonial. Não obstante os contributos trazidos por autores como Dauril Alden ou Marcos Carneiro de Mendonça, ${ }^{19}$ ignoramos no essencial o grau de dependência institucional das Juntas da Fazenda relativamente ao Erário Régio. Presumidamente, assume-se que tal subordinação seria enorme, porque, no limite, isso expressa melhor o teor reformador da iniciativa de Carvalho e Melo. Mas terá sido mesmo assim? Ou será que essa presunção não é mais do que o produto de uma "leitura unilateral de progresso pombalino", para usar os termos de José Esteves Pereira? ${ }^{20}$

Neste texto, são precisamente as modificações políticas introduzidas na administração ultramarina portuguesa, por força da iniciativa pombalina, que se seguiram, indagando os limites e as contradições inerentes ao processo de coabitação entre o Erário Régio e a Junta da Fazenda do Rio de Janeiro. Foram alvo de especial atenção duas matérias tradicionalmente sensíveis aos governos de Antigo Regime: os recursos financeiros para a guerra e a fiscalidade, por via da arrematação dos contratos. ${ }^{21}$

No plano da organização, o texto divide-se em duas partes. A primeira parte pretende sinteticamente pôr em evidência o significado político da criação do Erário Régio, destacando-se as repercussões sentidas pelos restantes tribunais e repartições do reino. A segunda parte aborda a forma como a jurisdição dessa instituição se estendeu à América portuguesa.

\footnotetext{
${ }^{17}$ Tais divergências foram, por exemplo, notadas por Nuno Gonçalo Monteiro, "As reformas na monarquia pluricontinental portuguesa: de Pombal a D. Rodrigo", In: João Fragoso; Maria de Fátima Gouvêa (orgs.), 0 Brasil colonial: 1720-1821, Rio de Janeiro, Civilização Brasileira, 2014, p. 112.

${ }^{18}$ Doravante e para facilitar o discurso, recorrer-se-á à expressão Junta da Fazenda.

${ }^{19}$ Dauril Alden, Royal government in Colonial Brazil, with special reference to the administration of the Marquis of Lavradio, Viceroy, 1769-77, Los Angeles, University of California Press, 1968, p. 279-352; Marcos Carneiro de Mendonça, O Erário Régio no Brasil, Rio de Janeiro, Ministério da Justiça, 1968. A esse respeito, ver também o trabalho de Ângelo Alves Carrara, Receitas e despesas da Real Fazenda do Brasil - século XVIII, Juiz de Fora, Editora da UFJF, 2009.

${ }^{20}$ José Esteves Pereira, "Teorização absolutista e centralização", In: __.., Percursos de história das ideias, Lisboa, INCM, 2004, p. 121.

${ }^{21}$ Num certo sentido, segue-se a sugestão do já referido José Damião Rodrigues. Para o historiador português, o significado da mudança política e cultural do Pombalismo deve ser preferencialmente recolhido na documentação administrativa e na correspondência do centro com a periferia e não nos escritos dos mentores do novo regime. José Damião Rodrigues, "'Para o Socego e tranquilidade publica das IIhas': fundamentos, ambição e limites das reformas pombalinas nos Açores", In: ___.. Histórias atlânticas: os Açores na primeira modernidade, 2. ed., Lisboa, CHAM, 2012, p. 208.
} 


\section{Antes do Erário Régio: alguns aspectos de dispersão político-administrativa}

A negligência de que tem sido alvo o Erário Régio enquanto objeto de estudo específico é tanto mais estranha quanto na altura da sua instituição foi tido como o ápice da administração Josefina. Jacome Ratton, por exemplo, referiu que se tratava "de um monumento que por si só bastaria para eternizar a memória deste grande Monarca".22 Não obstante o desconhecimento resultante do descuido acadêmico, é muito razoável defender a criação do Erário Régio como uma das principais alterações do sistema político português na segunda metade dos Setecentos.

De acordo com a lei de 22 de dezembro de 1761, o Erário Régio deveria passar a controlar "tão-somente" a generalidade dos rendimentos que antes se consignavam às demais repartições e tribunais. Instituiu-se, então, um tesourogeral onde deveriam ser recolhidos todos os rendimentos da monarquia, agora significativamente denominados "públicos". Por tal tesouro, deveriam ser igualmente suportadas todas as despesas. ${ }^{23}$ Dificilmente poderia existir maneira mais direta de restringir as autonomias e as jurisdições anteriores. De fato, até esse momento, muitas repartições e tribunais tinham autonomia para administrar rendas, direitos ou quaisquer outros bens que lhe tivessem sido concedidos, ${ }^{24}$ frequentemente para o cumprimento de funções atribuídas ou para o sustento dos seus membros (caso das propinas aplicadas sobre contratos). Assim era o caso, por exemplo, do Conselho Ultramarino, por onde, para fazer face à sua obrigação de socorrer as conquistas com munições e outros materiais, D. Pedro II ordenara que corresse parte das receitas ultramarinas que chegavam a Lisboa. ${ }^{25}$

Em regra, esses rendimentos eram recolhidos por contratadores, rendeiros, almoxarifes e recebedores e entregues na repartição estipulada, sendo as suas contas posteriormente conferidas em uma repartição específica (embora organicamente ligada ao Conselho da Fazenda): Contos do Reino e Casa. Tal era o procedimento adotado para o reino e, desde 1627, para todas as partes ultramarinas. ${ }^{26}$

A dispersão da administração de receitas e despesas da fazenda real estava para além dos espaços mais diretamente submetidos à Coroa. Por exemplo, no Brasil, até a década de 1720, várias câmaras municipais recolhiam e

\footnotetext{
22Jacome Ratton, Recordações de Jacome Ratton sobre ocorrências do seu tempo em Portugal de maio de 1747 a setembro de 1810, 4. ed., Lisboa, Fenda, 2007, p. 226.

${ }^{23}$ José Roberto M. C. Coelho Sousa, Systema, ou Collecção dos Regimentos Reaes, tomo III, Lisboa, Oficina de Francisco Borges de Sousa, 1785, p. 451-473.

${ }^{24}$ Álvaro Ferreira da Silva, "Finanças Públicas", In: Pedro Lains; Álvaro Ferreira da Silva (orgs.), História económica de Portugal - 1700-2000: o século XVIII, vol. 1, Lisboa, ICS, 2005, p. 225.

${ }^{25}$ Miguel Dantas da Cruz, O Conselho Ultramarino e a administração militar do Brasil (da Restauração ao Pombalismo): política, finanças e burocracia, Tese de doutorado, Instituto Universitário de Lisboa, Lisboa, 2013, p. 151-158.

${ }^{26} \mathrm{O}$ capítulo XVIII do regimento dos Contos revogou a prática de serem quitados nas próprias conquistas os oficiais que recebessem rendimentos da fazenda. Daí em diante, tudo deveria ser confirmado no reino (Regimento dos Contos, 1627). Cf. José Roberto M. C. Coelho Sousa, op cit., p. 367-446.
} 
administravam tributos destinados ao custeamento de despesas militares, por vezes, sem intervenção das provedorias. Quer isso dizer que, na América portuguesa, e ao contrário do que geralmente acontecia no reino (com a exceção das cidades do Porto e Setúbal), o qual haveria de contar com a intervenção da Junta dos Três Estados, os concelhos geriam livremente os recursos fiscais até o pagamento final das tropas em mostras, às quais exigiam estar presentes. ${ }^{27} \mathrm{O}$ período de guerra com os holandeses, em meados do século XVII, foi especialmente ilustrativo do protagonismo assumido pelas câmaras na coleta fiscal para posterior satisfação dos encargos com a tropa. ${ }^{28}$

Naturalmente, essa autonomia camarária não recolhia (provavelmente nunca recolheu) um consenso alargado e, a partir de 1711, começou a ser suprimida, primeiro na Bahia e depois em Pernambuco e no Rio de Janeiro. ${ }^{29}$ No seguimento da desestabilização provocada pela Guerra da Sucessão de Espanha, também no reino se discutiram as vantagens de retirar a cobrança das terças às câmaras. Os pareceres dos conselheiros de Estado dão conta de que os tempos estavam de fato a mudar para as autonomias municipais, ${ }^{30} \mathrm{e} \mathrm{o}$ mais significativo é que essa erosão do poder das edilidades precedia em 40 anos a chegada de Pombal. Só muito dificilmente se poderá imputar tal responsabilidade ao ministro de D. José I.

A título de comparação, note-se que esse mesmo período assistiu ao reforço do protagonismo político-militar dos poderes locais (no caso, assembleias coloniais) na América britânica, que tiraram pleno partido das ameaças franco-espanholas e das carências fiscais de Londres. ${ }^{31}$

Ainda no que tocava aos recursos para a defesa do Brasil, importa referir que a ausência de um ponto de coordenação geral esteve na origem de décadas de conflito permanente entre o Conselho Ultramarino e o Conselho da Fazenda (c.1705-c.1735). Os rendimentos destinados à aquisição e ao transporte de matérias de guerra para a Colônia, geridos pelo Conselho Ultramarino, e os rendimentos destinados ao custeamento dos navios da Coroa, administrados pelos Armazéns da Coroa, tendiam a confundir-se, transformando a proteção do Brasil em um enorme desafio para as articulações do sistema polissinodal português.

Ilustrativo da tensão provocada por tais dificuldades foi um parecer, emitido pelo então vedor dos Armazéns (marquês de Fronteira), onde se exigiu

\footnotetext{
${ }^{27}$ Biblioteca Nacional, Assentos da Câmara da Baía relativos aos fornecimentos das tropas de infantaria (julho de 1652), Documentos Históricos, vol. 79, Rio de Janeiro, 1948, p. 349-367.

${ }^{28}$ Ver, por exemplo: Evaldo Cabral de Mello, Olinda Restaurada: guerra e açúcar no Nordeste, 1630-1654, 2. ed., Rio de Janeiro, Topbooks, 1998; e Wolfgang Lenk, Guerra e Pacto Colonial: exército, fiscalidade e administração colonial da Bahia (1624-1654), Tese de doutorado, Universidade Estadual de Campinas, Campinas, 2009. ${ }^{29}$ Miguel Dantas da Cruz, O Conselho Ultramarino e a administração militar do Brasil (da Restauração ao Pombalismo): política, finanças e burocracia, Tese de doutorado, Instituto Universitário de Lisboa, Lisboa, 2013, p. 158-176. Sobre esse assunto, ver também Maria Fernanda Bicalho, "Inflexões da política imperial de D. João V", Anais de história de além-mar, n. 8, Lisboa, 2007, p. 37-67.

${ }^{30}$ Consulta do Conselho de Estado, de setembro de 1713. Academia das Ciências de Lisboa (ACL), Série Azul, n. 127, Papéis do Conselho de Estado, fls. 4-13v.

${ }^{31}$ lan Steele, "The anointed, the appointed, and the elected: governance of the British Empire, 1689-1784", In: P. J. Marshall (ed.), The Oxford history of British Empire: the eighteenth century, vol. 2, Oxford, Oxford University Press, 1998, p. 112
} 
a preservação das práticas entre os tribunais. D. Fernando de Mascarenhas sublinhou que o Conselho Ultramarino deveria pagar o que devia "porque neste Reino se observa inviolavelmente estilo, que passa por Lei, de que a dívida que se contraiu por um tribunal se não pague pelos bens que outro tribunal administra". ${ }^{32}$ Pela mesma altura, o mesmo aristocrata chegou a propor a incorporação do Conselho Ultramarino (e da Junta do Comércio) na Repartição dos Armazéns, o que, por outras palavras, implicava a extinção do primeiro. ${ }^{33}$ Para a Fronteira, só com a centralização do despacho das matérias das conquistas no Conselho da Fazenda, sobretudo na Repartição dos Armazéns, seria possível fazer convergir os múltiplos interesses envolvidos na administração ultramarina. Naquele momento, o plano de absorção institucional foi rejeitado. Porém, a sua contemplação nos principais círculos de poder da monarquia, inclusivamente em pareceres do duque de Cadaval, que o considerou um produto da desmedida ambição de Fronteira, ${ }^{34}$ ilustra a viabilidade com que foi encarado.

Esse cenário de certa anarquia sofreria uma modificação essencial com o estabelecimento do Erário Régio, em 1761. Financeiramente dependentes de um novo organismo, as repartições e tribunais da Coroa perderam não só influência como também a razão para se envolverem em disputas entre si. Num certo sentido, é legítimo referir que Carvalho e Melo disciplinou a generalidade do sistema político português quando lhes retirou a administração de consignações particulares. Salvo raras exceções, aliás, mais tarde corrigidas, ${ }^{35} \mathrm{O}$ espectro institucional português ficou numa espécie de subordinação implícita ao Erário e, consequentemente, ao seu inspetor-geral ou aos seus presidentes (de 1777 em diante). Na realidade, mais do que os poderes periféricos — caso das câmaras municipais - , as primeiras vítimas do Erário Régio podem muito bem ter sido as outras instâncias do poder central.

Em benefício da reflexão comparada, não é possível deixar de sublinhar a esse respeito as similitudes entre Carvalho e Melo e o inglês Walpole, que, à imagem de Pombal, também nunca gozou do estatuto de primeiro-ministro. Walpole pode não ter sido a principal referência de Carvalho e Melo, um pouco

\footnotetext{
${ }^{32}$ Parecer do marquês de Fronteira, provavelmente do período da Guerra da Sucessão de Espanha. Cf. Miguel Dantas da Cruz, O Conselho UItramarino e a administração militar do Brasil (da Restauração ao Pombalismo): política, finanças e burocracia, Tese de doutorado, Instituto Universitário de Lisboa, Lisboa, 2013, p. 205.

${ }^{33}$ Proposta do marquês de Fronteira, 24 de outubro de 1712. Cf. Virgínia Rau; Maria Gomes da Silva, Os manuscritos do Arquivo da Casa do Cadaval respeitantes ao Brasil, vol. II, doc. 161, Coimbra, Imprensa da Universidade, 1956-1958, p. 108-110.

${ }^{34}$ Parecer do Duque de Cadaval sobre a proposta de incorporação do Conselho Ultramarino e da Junta do Comércio na Repartição da Índia e Armazéns, 28 de novembro de 1712. Cf. Ibidem, doc. 164, p. 110-111.

${ }^{35} \mathrm{~A}$ maioria dos tribunais, como a Junta dos Três Estados, ficou de imediato na dependência do Erário Régio; outros, porém, mantiveram alguma forma de autonomia que, de qualquer modo, não durou muitos anos. Foram os casos da administração da Casa de Bragança (1765); da Casa das Rainhas (1769); dos Contos da Mesa da Consciência e Ordens, Contadorias das Três ordens Militares e da Tesouraria Geral dos Cativos (1774); do donativo dos 4\% (administrado pela Junta do Comércio até 1780); e da Contadoria do Subsídio Literário (1794). No início do século XIX, seriam raros os rendimentos "públicos" não diretamente absorvidos pelo Erário. Cf. Alzira Teixeira Leite Moreira, Inventário do Fundo Geral do Erário Régio, Lisboa, Tipografia Minerva do Comércio, 1977, p. xiv-xvi.
} 
ao contrário do que sustentou Hamish Scott. ${ }^{36}$ No entanto, o fato de Pombal se ter colocado à cabeça do Erário Régio, como inspetor-geral, denuncia a inspiração britânica desse seu projeto. É que também Walpole reforçou a sua posição política por via do exercício do cargo de First Lord of the Treasury, cargo que viria a ficar sintomaticamente vinculado ao de primeiro-ministro na Grã-Bretanha.

\section{O Erário Régio e o controle político dos territórios ultramarinos}

A constituição de um ponto central para a arrecadação da Fazenda Real, exclusivamente administrado pelo Erário Régio, limitou fortemente, portanto, a capacidade de os demais tribunais atuarem livremente, impossibilitando-os de emitir ordens de pagamento, mesmo quando as matérias eram por si tuteladas. Na prática, o Erário Régio passava a controlar o funcionamento dos restantes órgãos de governo, transferindo verbas para onde fosse necessário.

\section{Carvalho e Melo disciplinou a generalidade do sistema politico português quando lhes retirou a administração de consignações particulares}

A administração das conquistas não foi diferente. Os tribunais e repartições da administração central que, de alguma forma, intervinham na gestão do ultramar, sobretudo o Conselho Ultramarino, eram agora compelidos a elaborar as folhas que deveriam ser obrigatoriamente remetidas ao Erário Régio, para posterior expedição dos mandatos de pagamento. A única exceção prevista a esse procedimento pressupunha carta assinada pela "Real Mão", que, sem prejuízo da indispensável participação ao presidente do Erário, autorizaria o pagamento de qualquer importância. Na eventualidade de uma urgência, relacionada com "algumas despesas e pagamentos no Brasil", os presidentes dos diferentes tribunais ou repartições deveriam tratar pessoalmente com o presidente do Erário, para que por ele se mandasse expedir as "Ordens necessárias". Os presidentes do Erário Régio (e, antes deles, o inspetor-geral) podiam, por seu turno, questionar e mandar averiguar junto dos tribunais os motivos subjacentes às despesas feitas. Podiam também mandar aferir quais as resoluções régias em que elas se apoiavam. Há nessas soluções administrativas um indelével traço de contemporaneidade.

As matérias que a lei de 22 de dezembro de 1761 deixou omissas e que estariam na origem da perpetuação de práticas contrárias ao espírito do diploma, foram corrigidas anos mais tarde, já depois do afastamento de Carvalho e Melo.

${ }^{36}$ Hamish Scott, "The rise of the first minister in the Eighteenth-Century Europe", In: T. C. Blanning; David Cannadine, History and biography. Essays in hounour of Dereck Beales, Cambridge, Cambridge University Press, 1996, p. 21-52. 
$\mathrm{Na}$ altura, foi especialmente contemplado o caso das conquistas. Relembrou-se, então, ao Conselho Ultramarino (e a todos os outros) a proibição de autorizarem a liquidação de despesas. ${ }^{37}$ Cumpre também sublinhar o insucesso das objeções veiculadas posteriormente acerca da subordinação ao Erário, como aconteceu já em 1800, quando a Junta da Fazenda da Marinha (criada especificamente para gerir o aprovisionamento e a construção de navios) se viu forçada a acatar as instruções orçamentais transmitidas pelo Erário. ${ }^{38}$

A marginalização do Conselho Ultramarino não ficou certamente por aqui. Ainda que subissem por esse tribunal muitos papéis relacionados com pagamentos, despesas ou tributos, era sobretudo no Erário que se despachavam. Por isso, muitos requerimentos encaminhados para o Conselho Ultramarino não obtiveram aí a resposta desejada. Tal foi o caso da frustrada representação dos oficiais da Câmara do Sabará sobre as dificuldades que encontravam para pagar os soldos dos sargentos-mores e ajudantes, entretanto nomeados para disciplinar as tropas auxiliares (1777). ${ }^{39}$

Pela mesma ordem de razão, foi também no Erário que se passaram a dirimir disputas administrativas entre capitanias, frequentemente relacionadas com o controle de certos recursos ou com o desejado direito a arrematar contratos. Por exemplo, no final da década de 1760, e depois de se ter verificado que os contratos das passagens de Curitiba e Viamão tinham sido arrematados por São Paulo e pelo Rio de Janeiro, a capital fluminense foi advertida para não se intrometer naqueles negócios. ${ }^{40}$ Ordem que foi reforçada pelo próprio Conde de Oeiras, quando referiu explicitamente "que por essa Junta da Fazenda se não torne a rematar daqui em diante os contratos dos governos do Brasil relativos aos distritos das outras Capitanias Gerais e os das Capitanias Mores a eles subordinados, mas sim e tão-somente fará rematar os que se compreenderem no território dessa Capitania". ${ }^{41}$

Entre os órgãos do poder central, foi nas secretárias de Estado que o Erário encontrou mais obstáculos à observação das suas diretrizes, sobretudo depois da queda de Pombal, que era simultaneamente secretário de Estado do reino e inspetor-geral. À partida, as esferas de intervenção estariam bem definidas, pelo menos segundo a interpretação de Carvalho e Melo. Por exemplo, no início da década de 1770, o marquês do Lavradio, Vice-rei do Brasil, propôs a Pombal uma alteração que passava pela maior regularidade com que se conferiam as contas aos almoxarifes na Junta da Fazenda do Rio de Janeiro. Contudo, fê-lo por via da Secretaria de Estado do Reino, o que não podia agradar ao ministro de D. José I, sempre organizado nos assuntos de Estado. O Vice-rei foi então recordado do circuito por onde deveria transitar aquela proposta, que

\footnotetext{
${ }^{37}$ Decreto de 12 de junho de 1779. Cf. António Delgado da Silva, Collecção da Legislação Portugueza Suplemento à Legislação de 1763 a 1790, Lisboa, Typografia Maigrense, 1844, p. 471-473.

${ }^{38}$ Consulta da Junta da Fazenda da Marinha, de 22 de agosto de 1800. Biblioteca Central da Marinha - Arquivo Histórico (BCM-AH), Livro 2.384, fls. 212v-213.

${ }^{39}$ Representação dos oficiais da Câmara do Sabará. De 4 de agosto de 1777. Arquivo Histórico Ultramarino (AHU), Avulsos, Minas, cx. 111, doc. 47 (8.842).

40provisão de 13 de julho de 1769. Tribunal de Contas (TC), Erário Régio (ER), n. 4.055, fl. 108.

${ }^{41}$ Carta do Conde de Oeiras de 29 de agosto de 1769. TC, ER, n. 4.055, fls. 115-116.
} 
Carvalho e Melo não deixava de considerar interessante: "É muito próprio o projeto de estabelecer um método perpétuo e inalterável para se governarem as Provedorias sujeitas a essa Capitania, o qual deve Vossa Excelência remeter ao Erário Régio, para que Sua majestade à vista dele, o aprove no que lhe parecer justo".42

Os embates jurisdicionais seriam, no entanto, mais ou menos inevitáveis com um espaço de poder cuja margem de intervenção precedia a chegada de Carvalho e Melo. ${ }^{43}$ A este respeito, a questão da proteção do Brasil, porque tinha uma componente político-militar e uma componente financeira, seria particularmente propensa a causar desentendimentos, que de fato aconteceram. Por exemplo, por ocasião da chegada ao Rio de Janeiro da frota do ano de 1791, a Junta da Fazenda local participou ao Erário que já não tinha condições para continuar a custear sozinha os gastos provocados pelos navios de guerra do comboio (problema que estava longe de ser novo ${ }^{44}$ ). Pediu, então, para se libertar daquele encargo, levantando a possibilidade de aqueles navios fazerem os seus reabastecimentos em outros portos da costa brasileira. Em Lisboa, e porque sentiu que se tratava de uma matéria que exorbitava o seu quadro de funções, o Erário preferiu encaminhar a participação para o secretário da Marinha, Martinho de Melo e Castro, não deixando, contudo, de vincar bem a sua posição junto de D. Maria I:

Como as despesas com as ditas embarcações declara a Junta se costumam fazer por ordens expedidas nas respetivas conjunturas, as quais considero serem emanadas da Secretaria de Estado dos Negócios da Marinha e dos Domínios Ultramarinos, sendo certo, que por decreto de 12 de Junho de 1779 [a que já se aludiu] ficou privativo ao Tribunal deste Real Erário da expedição das Ordens para qualquer pagamento da Real Fazenda, ainda [que] relativo àqueles Domínios; para se obviar inconciliável contradição às mesmas ordens, na que se deve expedir em consequência desta Conta; parece, que só Sua Majestade pode determinar ao que for mais conforme ao seu Real Agrado. ${ }^{45}$

As observações feitas por D. Fernando José de Portugal (penúltimo Vice-rei do Brasil) ao capítulo 32 do Regimento de Roque da Costa Barreto confirmam a persistência das dificuldades associadas àquela convivência. $\mathrm{O}$ futuro marquês de Aguiar referiu que no Rio de Janeiro, no início de Oitocentos, ainda se recebiam ordens da Secretaria de Estado da Marinha que acabavam por originar

\footnotetext{
${ }^{42}$ Carta de Pombal para Lavradio, de 20 de fevereiro de 1770. Marcos Carneiro de Mendonça, O século XVIII: século pombalino do Brasil, Rio de Janeiro, Xerox, 1989, p. 513-514. Dois anos depois, por provisão dirigida à Junta da Fazenda fluminense (via Erário Régio), a proposta de Lavradio acabou por ser mesmo aprovada. Provisão de 18 de setembro de 1772. TC, ER, n. 4.055, fls. 164-165.

${ }^{43}$ André da Silva Costa, Os secretários e o Estado do rel: luta de corte e poder político (séculos XVI-XVII), Lisboa, Dissertação de mestrado, Universidade Nova de Lisboa, Lisboa, 2008.

${ }^{44}$ Miguel Dantas da Cruz, O Conselho Ultramarino e a administração militar do Brasil (da Restauração ao Pombalismo): política, finanças e burocracia, Tese de doutorado, Instituto Universitário de Lisboa, Lisboa, 2013, p. 198-212.

${ }^{45}$ Exposição do Contador Geral de 19 de novembro de 1791 (à margem: representação enviada a Martinho de Melo e Castro). TC, ER, n. 4044, fls. 110-112.
} 
algum tipo de dispêndio da fazenda real. E, ao contrário do que estava prescrito na lei de 22 de dezembro de 1761, muitas dessas ordens não eram assinadas pela "Real Mão". Todavia, apontou que fazia "constar" todo esse tipo de ordens na Junta da Fazenda fluminense, por onde se informava o presidente do Erário. ${ }^{46}$

\section{Dependências estruturais. A orgânica do sistema}

No império, o Erário Régio deveria atuar por via do sistema de Juntas da Fazenda, que foram sendo estabelecidas com maior ou menor dificuldade. Em princípio, tratava-se de uma relação hierarquizada feita num quadro de evidente subordinação que importa esmiuçar.

Cada Junta da Fazenda integrava-se na estrutura encimada pelo Erário Régio por via de uma contadoria geral que, em Lisboa, filtrava e enformava boa parte da comunicação dirigida ao monarca ou ao inspetor-geral/presidente do Erário. A comunicação podia ser feita pelo corpo da Junta, mas também a título individual por cada um dos seus membros. Parece, contudo, que somente os seus presidentes, ou seja, Vice-reis e governadores, teriam acesso direto ao inspetor-geral e ao rei. Os restantes membros da Junta escreviam necessariamente para o contador-geral, em Lisboa. Importa notar que tal privilégio não isentava a correspondência dos presidentes das Juntas da Fazenda do escrutínio (muitas vezes, crítico) do contador-geral, mesmo quando a comunicação chegava via Secretaria de Estado.

A composição das Juntas variou de capitania para capitania, mas tendeu a incorporar cargos tradicionais, caso do provedor, que, entretanto, perdeu muita autonomia, e ofícios mais recentes (como se pode ver na Figura 1), especificamente enviados para o Brasil com o propósito de introduzir o método de partidas dobradas. A esse respeito, dois homens (dois escrivães) merecem uma chamada de atenção: João Correia Lemos, que se manteve no Rio de Janeiro até 1799, e Sebastião Francisco Betâmio, que deu corpo a uma carreira verdadeiramente atlântica, servindo na Bahia, São Paulo, Rio Grande do Sul e Angola.

Para além da subordinação funcional inscrita no diploma constitutivo, que, por exemplo, negou às Juntas o uso de jurisdição contenciosa em matérias da fazenda real, ${ }^{47}$ existem sinais que Lisboa terá procurado controlá-las a outros níveis. Ilustrativo dessa ambição foi provavelmente a colegialidade imposta no processo decisório, ${ }^{48}$ que se mandou observar, não obstante a incontornável preeminência dos presidentes. ${ }^{49}$

\footnotetext{
${ }^{46}$ Regimento que trouxe Roque da Costa Barreto, mestre de campo general, em data de 23 de janeiro de 1677, com várias observações feitas pelo atual Vice-Rei... Biblioteca Nacional do Rio de Janeiro (BNRJ), 09, 02, 026, fls. 45v-48v. ${ }^{47}$ Houve expectáveis reclamações, que, contudo, não foram bem-sucedidas. Cf. Cartas do Vice-rei, o Conde da Cunha, provedor da Fazenda, procurador da Coroa e Fazenda e Chanceler da Relação (1766). AHU, Avulsos, Rio de Janeiro, cx. 78, doc. 7.080.

${ }^{48} \mathrm{~A}$ esse respeito, Iris Kantor detectou uma tendência mais geral, falando mesmo do reforço da administração colegiada nos governos ultramarinos. Íris Kantor, Esquecidos e renascidos: historiografia acadêmica lusoamericana (1724-1759), São Paulo, Hucitec, 2003, p. 119.

${ }^{49}$ Dauril Alden, recorrendo sobretudo ao caso do Rio de Janeiro, durante o governo do Marquês de Lavradio, sublinhou que a Junta fluminense foi, no essencial, dominada pelo Vice-rei. Dauril Alden, Royal government in Colonial Brazil, with special reference to the administration of the Marquis of Lavradio, Viceroy, 1769-77, Los Angeles, University of California Press, 1968, p. 282. Veremos mais à frente que isso nem sempre aconteceu.
} 


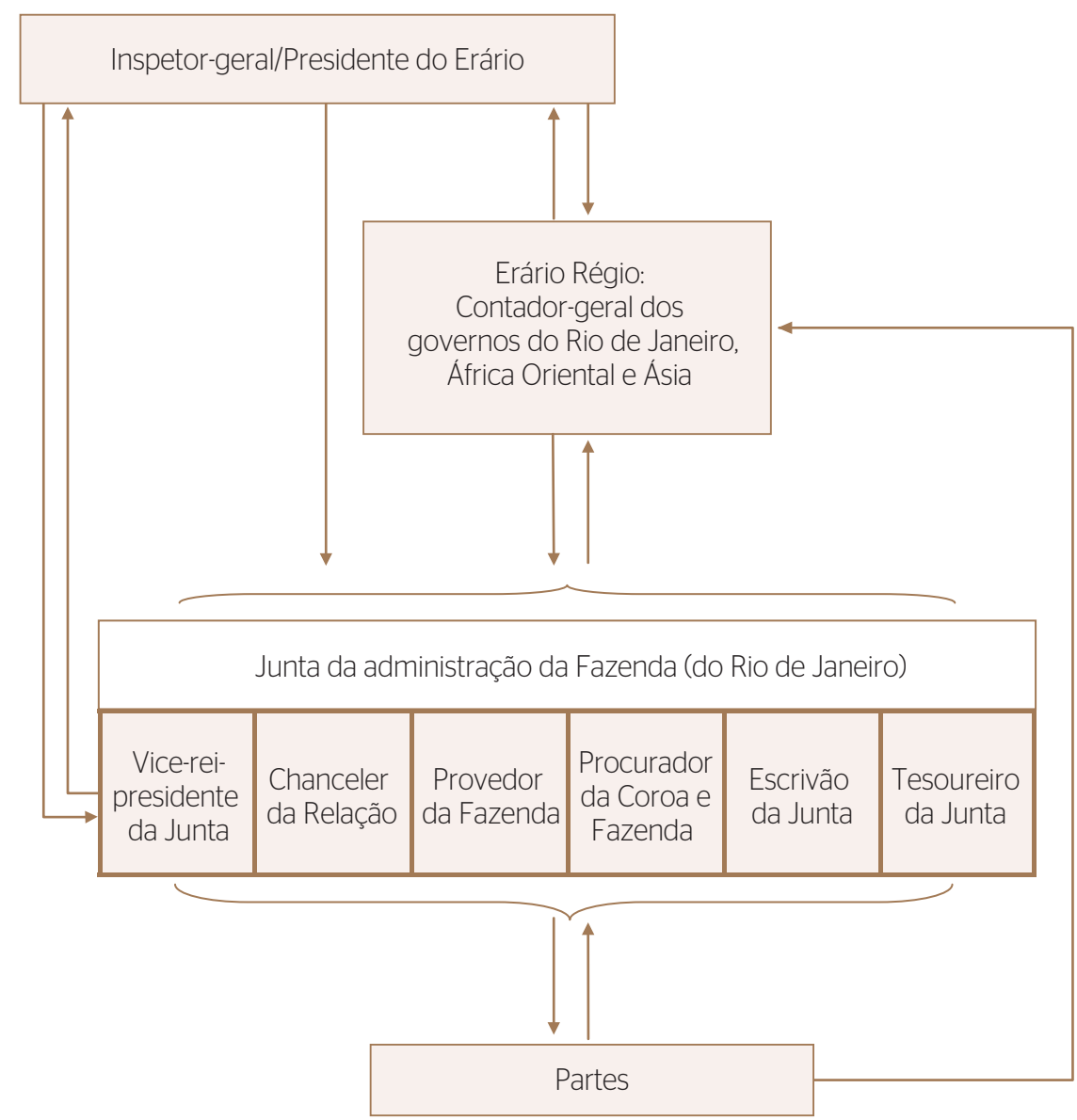

Figura 1. Base do circuito de comunicação Erário Régio-Junta da Fazenda do Rio de Janeiro.

A chegada do escrivão João Correia Lemos e do tesoureiro-mor ao Rio de Janeiro foi de pronto acompanhada por instruções que lhes atribuíam um lugar na Junta da Fazenda em condições de absoluta paridade com os demais membros: "terão na mesma Junta o assento espaldar do mesmo modo em que o têm os Ministros pelas respectivas antiguidades reguladas pelas posses que cada um tomar". Mais importante, explicitava-se que o voto do "truculento", mas hábil escrivão (daí a confiança que lhe concedia Carvalho e Melo ${ }^{50}$ ), e do referido tesoureiro seria indispensável nas "matérias próprias da dita Junta que nela se tratarem, como pessoas versadas na formalidade e método das contas

\footnotetext{
50 João Correia Lemos seguiu para o Rio de Janeiro em 1767, com o propósito de introduzir o método de partidas dobradas. Seria um homem da inteira confiança de Pombal, um dos poucos que, no reino, tinha conhecimento apurado do famoso método inventado pelos venezianos. A resolução dada a um desentendimento que teve com Alexandre Nunes, procurador da Coroa, testemunha o apoio que contava em Lisboa: o magistrado foi preso e enviado para a capital do império. Anos mais tarde, Lavradio considerava Correia Lemos absolutamente intratável, mas reconhecia os seus méritos, indispensáveis para o bom funcionamento da Junta do Rio de Janeiro. Dauril Alden, Royal government in Colonial Brazil, with special reference to the administration of the Marquis of Lavradio, Viceroy, 1769-77, Los Angeles, University of California Press, 1968, p. 314.
} 
na Administração das rendas, e arrecadação delas". ${ }^{51}$ O mesmo documento (da concessão da paridade ao escrivão) exigia também que os despachos relativos às despesas fossem sempre assinados por todos os membros. Referia-se, então, que "todos os papéis que hão de servir de título para despacho do referido tesoureiro-geral serão autorizados com as rubricas de todo o corpo da Junta".

Não é claro se a colegialidade imposta ao modus operandi das Juntas visava diminuir objetivamente o ascendente natural dos governadores/Vice-reis, mas não há dúvida que alguns deles se sentiram condicionados, criticando desconsoladamente tal prescrição. Num certo sentido, as Juntas, por via do seu funcionamento, constituíam agentes ativos no reforço da capacidade de decisão lisboeta, limitando a jurisdição dos governadores quando exercida de forma desenquadrada daquele corpo. Um caso verificado durante o governo de Antônio Carlos Furtado de Mendonça, em Minas Gerais (1773-1775), mostra como o estabelecimento de uma Junta da Fazenda num território muito especial - alvo tradicional de impulsos centrípetos da Coroa,$-{ }^{52}$ se refletiu na diminuição da jurisdição dos governadores.

Entre os órgãos do poder central, foi nas
secretárias de Estado que o Erário encontrou
mais obstáculos à observação das suas diretrizes,
sobretudo depois da queda de Pombal

Informado pelo tesoureiro-geral da Junta da Fazenda de Minas Gerais acerca do comportamento de Furtado de Mendonça, que suspendera o novo método de escrituração e determinara que a "despesa daquela repartição fosse feita somente por despachos do governador [...] dirigidos ao provedor da Fazenda", o contador-geral, em Lisboa, participou o sucedido ao então Conde de Oeiras. Referiu, então, que a "má forma e irregularidade com que a Fazenda Real era administrada na América deram o motivo do estabelecimento das Juntas da Fazenda, às quais foi Sua Majestade servido encarregar toda a administração da Sua Fazenda sem exceção de ramo algum". Todavia, e ainda segundo o contador-geral, alguns governadores ficaram muito insatisfeitos com "o tirar-se lhes a mesma administração das suas disposições", e procuravam manter a sua anterior jurisdição. Tal seria inaceitável e, segundo a exposição de Luís José de Brito, "muito contrária às ordens de Sua Majestade"; por isso, o próprio contador-geral tomou a iniciativa de elaborar a provisão, que submeteu à ratificação de Carvalho e Melo, e que deveria ser enviada para Minas com o objetivo de corrigir aquele procedimento adotado pelo governador. ${ }^{53}$ No mesmo dia, a

\footnotetext{
${ }^{51}$ Carta do Conde de Oeiras para o Conde de Azambuja, de 6 de abril de 1769. TC, ER, n. 4.103, fls. 261-263. ${ }^{52} \mathrm{~A}$ esse respeito, ver o levantamento historiográfico de Júnia Ferreira Furtado, "Novas tendências da historiografia sobre Minas Gerais no período colonial", História da historiografia, n. 2, 2009, p. 116-162. ${ }^{53}$ Exposição de Luís José de Brito, de 13 de março de 1776. TC, ER, n. 4.048, fls. 52-52v.
} 
provisão foi assinada e despachada, referindo-se explicitamente que jamais deveria "o tesoureiro-geral respectivo fazer despesa alguma pertencente àquela repartição que não seja por despacho da mesma Junta".54

A supressão do direito que por tradição assistia aos principais governadores de proverem privativamente as serventias dos ofícios da fazenda e da justiça reflete de alguma forma este condicionamento, em favor das Juntas. Na capitania do Rio de Janeiro, em outubro de 1761, o poder de decisão sobre esta importante matéria (diretamente relacionado com a formação de clientelas) foi canalizado para a Junta da Fazenda, ${ }^{55}$ onde se passaram a arrendar todos os ofícios da capitania, com exceção das propriedades e das serventias vitalícias, que se mantiveram reservadas ao arbítrio do monarca. ${ }^{56}$

A resistência que os governadores vieram a oferecer a esta determinação foi definitivamente debelada quando em agosto de 1799, por provisão do Erário Régio, se confirmou a prerrogativa da Junta fluminense. Foi, portanto, com evidente desagrado que o já referido D. Fernando José de Portugal (ao comentar o capítulo 7 do Regimento do governador-geral do Brasil) escreveu que a Junta da Fazenda do Rio de Janeiro provia a serventia de todos os ofícios da capitania, quer fossem da fazenda, quer fossem da justiça. Ao Vice-rei, passara somente a caber o provimento das serventias dos ofícios da Relação do Rio de Janeiro, "quando pelo seu regimento e pelos das Relações da Baía e do Rio de Janeiro podia prover uns e outros",57 ou seja, todos (os da fazenda e da justiça).

\section{Autonomias concedidas: sinais de racionalização administrativa}

O quadro descrito evidencia o caráter essencialmente centralizador da reforma posta em prática por Carvalho e Melo. Existem, porém, indícios que apontam em sentido contrário e cujo significado importa apreender. É que o referido reforço da administração colegiada nos governos ultramarinos foi acompanhado por um menos discutido alargamento de competências.

Às Juntas foi, portanto, delegado um poder formal que em certos aspectos ultrapassou bastante o quadro de funções anteriormente concedido à administração periférica da coroa na América portuguesa. Por exemplo, a prestação de contas de todos os oficiais que recebiam ou despendiam rendas reais passou a ser grandemente assegurada nos territórios que se encontravam debaixo da influência da respectiva Junta. De 1760 em diante, os tesoureiros, almoxarifes e recebedores da fazenda real deixaram de ser obrigados a prestar contas em Lisboa, mais precisamente aos Contos do Reino e Casa. A explicação para essa súbita mudança encontra-se na carta régia de 18 de agosto de 1760 . Aí se referia que os homens mais abonados (das conquistas) rejeitavam servir os

\footnotetext{
54Provisão de 13 de março de 1776. TC, ER, n. 4.073, fls. 322-323. ${ }^{55}$ Carta régia de 24 de outubro de 1761. Instituto Histórico e Geográfico Brasileiro (IHGB), lata 22O, doc. 1 ${ }^{56}$ BNRJ, 09, 02, 026, fls. 7-12v.

57Ibidem.
} 
ofícios da fazenda por causa das muitas "dilações" a que "comumente" estavam sujeitos nos Contos. ${ }^{58}$

O acerto passou a ser feito na contadoria anexa à Junta, de onde se extraiam as cartas de quitação interinas, posteriormente expedidas para ratificação final em Lisboa (naquele ano de 1760 a conferência seria feita no Conselho Ultramarino e na Secretaria de Estado, mas, de 1761 em diante, caberia ao Erário Régio aprovar tais ajustes). Importa notar que a conferência de contas não se fazia apenas aos ofícios de menor consideração, que naturalmente administravam pequenas somas. O próprio tesoureiro-geral das tropas, Manuel Joaquim de Azevedo, que durante a crise luso-espanhola de 1774-1777 efetuou pagamentos a um exército que só no Rio Grande do Sul contava com mais 6.300 homens, ${ }^{59}$ acertou as suas contas na Junta da Fazenda do Rio de Janeiro e só depois pôde regressar ao reino. ${ }^{60}$

O controle que passou a exercer sobre outras instituições locais é também um importante testemunho da margem de manobra outorgada à mesma Junta. Repare-se que, sob a tutela da Junta da Fazenda do Rio de Janeiro, ficaram: a Tesouraria Geral, a Contadoria, a Provedoria, a Casa da Moeda, a Alfândega e ainda a Junta das Fragatas (tribunal temporário, posto a funcionar sempre que chegava um navio de guerra ao porto). No caso da Alfândega, a Junta pôde intrometer-se na gestão dos recursos humanos que lhe estavam adstritos, passando, por exemplo, a nomear "os oficiais que lhe parecerem mais idôneos para bem exercerem os ofícios da Alfândega". Podia mesmo arbitrar-lhes os ordenados, sobrepondo-se em tudo ao provedor e ao administrador da Alfândega. ${ }^{61}$

Por último, mas não menos importante, destaca-se a centralidade assumida pela Junta da Fazenda do Rio de Janeiro na gestão da generalidade dos tributos cobrados na capitania, com exceção das receitas da Mesa da Inspeção. Mesmo o rendimento da Casa da moeda do Rio de Janeiro, para insatisfação do seu provedor, passou a ser entregue na Tesouraria Geral da Junta, de onde era despachado para Lisboa. ${ }^{62}$

À imagem do que acontecia no reino, as Juntas da Fazenda terão beneficiado de uma tendência que valorizou a convergência de competências de âmbito financeiro. Tratar-se-ia de um refinamento institucional que a jusante, e por via da delegação de certas funções, produziu uma certa forma de descentralização de rotinas no quadro da administração ultramarina. Ou seja, as Juntas, ao concentrarem poderes e competências na sua área de jurisdição, estariam a cumprir os objetivos da racionalização de procedimentos imposta por Carvalho e Melo. Não se tratava (provavelmente nunca se tratou) de fazer confluir para Lisboa todas as decisões. Pelo menos no que tocava ao funcionamento do

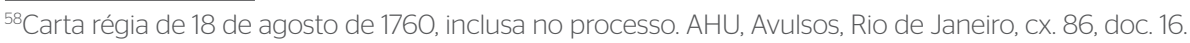
${ }^{59}$ Enrique Peregalli, Recrutamento militar no Brasil colonial, Campinas, Editora da UNICAMP, 1986, p. 99. 60Provisão de 19 de agosto de 1779, em que Manuel Joaquim de Azevedo recebeu a quitação geral da rainha, depois de terem sido vistas as 3 cartas de quitação passadas pela Junta da Fazenda do Rio de Janeiro. TC, ER, n. 4.055, fl. 493.

"IProvisão de 26 de agosto de 1769. TC, ER, n. 4.055, fls. 114-115.

${ }^{62}$ Carta do Conde de Oeiras para o provedor da Casa da Moeda, de 13 de agosto de 1767. TC, ER, n. 4.103, fls. 143-144.
} 
novo aparelho fazendário do império - fundado na relação de subordinação explícita das Juntas da fazenda americanas ao Erário Régio - , o afã reformador de Carvalho e Melo deve ser visto à luz dessa ideia de delegação formal e racionalizada de poderes.

O relevo adquirido pelas Juntas no espectro institucional da governação da América portuguesa pode ser confirmado na reação de D. Rodrigo de Sousa Coutinho a uma representação do Senado da Câmara do Rio de Janeiro, expedida em 1798, no sentido de fazer regressar à jurisdição das câmaras algumas das competências que, entretanto, lhes tinham sido retiradas (inclusive a administração da fazenda real). O Conselho Ultramarino foi então convidado a dar o seu parecer acerca da longa petição daquele município, "com a exceção de tudo o que pode dizer respeito a tirar a administração das Rendas das Juntas da Fazenda". Tal retrocesso administrativo era incompatível com as conhecidas preocupações fiscais do então secretário de Estado da Marinha: ${ }^{63}$ no essencial, o fisco deveria ser preservado nas mãos do Estado. De acordo com o futuro presidente do Erário Régio, devolver a administração dos rendimentos régios às câmaras era "contrário aos mais fundados princípios de toda a Pública e Econômica Administração" ${ }^{4}$

\section{Insubmissões imprevistas}

A sujeição estrutural das Juntas ao inspetor-geral e presidentes do Erário Régio, inequívoca ao nível do enquadramento legal, foi de certa forma compensada pela concessão de uma margem de manobra assinalável, mesmo em matérias a que Lisboa sempre fora muito sensível (provimentos e acertos de contas). É, todavia, legítimo referir que estas manifestações de autonomia foram em todos os casos previamente consentidas e até programadas, e que o seu único propósito correspondeu a algumas cedências de ordem prática por parte de um aparelho que se queria tão hierarquizado quanto possível.

Tal argumento é sólido, mas, de modo algum, equivale a dizer que no território brasileiro a administração periférica da coroa, entretanto reconfigurada, tivesse incorporado obedientemente todas as prescrições provenientes do Erário (do qual formalmente dependia). O caminho definido inicialmente por Carvalho e Melo esteve longe de ser pacífico e, independentemente do motivo, o Erário Régio nem sempre conseguiu impor-se sobre um território distante e sujeito a circunstâncias que Lisboa não podia controlar.

De seguida, abordar-se-ão dois problemas determinantes na relação mantida entre o Erário Régio e a Junta da Fazenda do Rio de Janeiro, ilustrativos do percurso particularmente acidentado da centralização, enquanto processo de decisão política, financeira e militar.

\footnotetext{
63Sobre a abordagem fiscal de D. Rodrigo, ver: José Luís Cardoso; Alexandre Mendes Cunha, "Discurso econômico e política colonial no Império Luso-Brasileiro (1750-1808)", Tempo, vol. 16, n. 31, 2011, p. 82-85.

${ }^{64}$ Aviso de D. Rodrigo de Sousa Coutinho ao Conselho Ultramarino, de 20 de agosto de 1799. AHU, Avulsos, Rio de Janeiro, cx. 180, doc. 36; cx. 175, doc. 86; cx. 176, doc. 45; cx. 168, doc. 12.536.
} 


\section{As arrematações e a sua localização}

O primeiro problema remete para uma espécie de combate institucional que envolveu a Junta fluminense e o Erário pelo direito a arrematarem contratos. A escolha não é obviamente inocente, já que a arrematação de contratos tanto mexia com a vontade fiscalista da Coroa (que se distinguiu dos parceiros europeus pelo peso atribuído aos monopólios na rubrica das receitas patrimoniais $^{65}$ ), como mexia com a influência de redes mais ou menos subterrâneas, que estariam pouco dispostas a ver despromovido um espaço de arrematação que controlavam.

Longe de ser completamente exaustivo, o Gráfico 1 permite perceber sem dificuldades as linhas de força da questão da localização dos espaços de arrematação dos contratos no Brasil meridional nas últimas décadas de Setecentos. Como já foi anteriormente sublinhado, parece ficar claro que a generalidade dos contratos passou a ser arrematada nas conquistas. Tratou-se de uma reorientação geográfica que em grande medida marginalizou o Conselho Ultramarino. Apesar de não ter ficado totalmente arredado deste negócio, o tribunal estava agora muito longe do protagonismo que D. João V lhe quis atribuir. ${ }^{66}$

\section{As Juntas, por via do seu funcionamento, constituíam agentes ativos no reforço da capacidade de decisão lisboeta, limitando a jurisdição dos governadores}

A transferência da decisão sobre matéria tão delicada constitui uma relocalização de poder, operada em prejuízo de uma instituição do centro da monarquia (o Conselho Ultramarino) e para benefício de uma instância da administração periférica (as Juntas da Fazenda). Ainda que pareça estranho o sentido dessa mudança, ela não se encontra desajustada do caráter mais geral da postura pombalina relativamente ao Conselho Ultramarino, marcada por uma certa hostilidade. ${ }^{67}$ Para Carvalho e Melo, as Juntas da Fazenda ofereceriam outras garantias de lealdade, apesar da distância a que se encontravam

\footnotetext{
${ }^{65}$ Álvaro Ferreira da Silva, "Finanças Públicas", In: Pedro Lains; Álvaro Ferreira da Silva (orgs.), História económica de Portugal - 1700-2000: o século XVIII, vol. 1, Lisboa, ICS, 2005, p. 252.

${ }^{66}$ É desconcertante seguir o sentido das disposições legais que, durante a primeira metade do século XVIII, se enviavam para o Brasil com o objetivo de ordenar a arrematação de contratos. A resolução régia de 10 de maio de 1723 referiu explicitamente que "todos os contratos que são da minha Real Fazenda se arrematem nesta Corte por tempo de três anos ainda os que são anuais" (Biblioteca Nacional, Documentos Históricos, vol. 1, Rio de Janeiro, 1927, p. 92-93). Em 26 de março de 1733, a decisão sobre a arrematação dos contratos é de novo transferida para o Brasil (Ibidem, p. 372-373). Em outra resolução, tomada em consulta do Conselho Ultramarino, com a data de 2 de março de 1736, corrigia-se a mão, passando a ser de novo obrigatório arrematar os contratos no Conselho Ultramarino (Ibidem, p. 291-292).

${ }^{67}$ Provavelmente, a maior demonstração dessa hostilidade aconteceu em 22 de novembro de 1765, quando vários governadores da América portuguesa receberam ordens para não enviarem cópias ao Conselho Ultramarino de qualquer comunicação mantida com as Secretárias de Estado. Cf. Dauril Alden, Royal government in Colonial Brazil, with special reference to the administration of the Marquis of Lavradio, Viceroy, 1769-77, Los Angeles, University of California Press, 1968, p. 10
} 


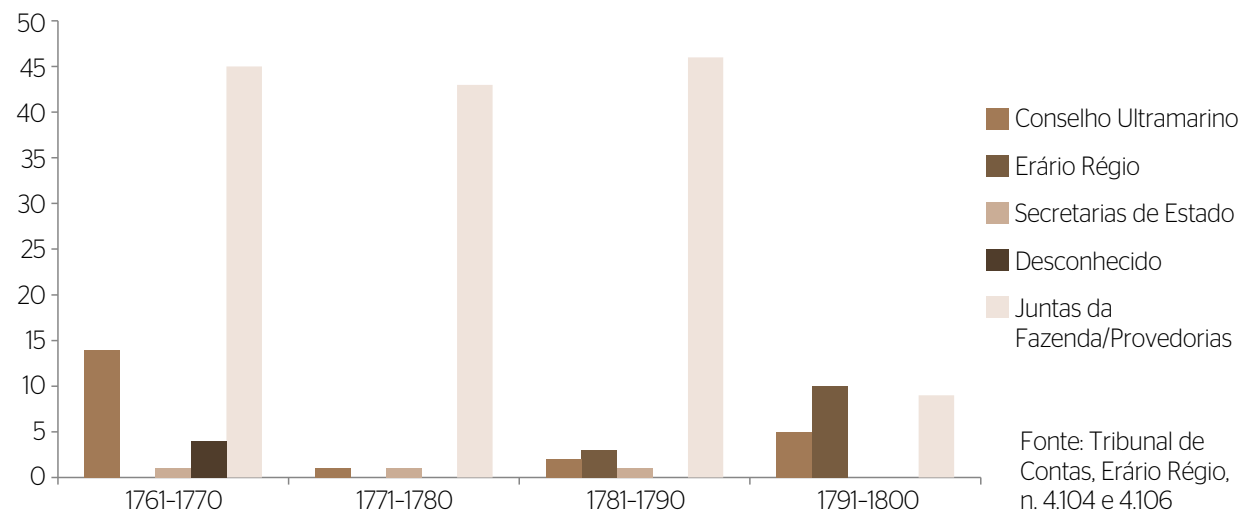

Gráfico 1. Espaço de arrematação dos Contratos da América Meridional Portuguesa.

de Lisboa. A dependência explícita de uma instituição que ele criara e dirigia seria a este respeito um elemento decisivo.

A justificação formal para a concessão daquele direito às Juntas da Fazenda encontra-se em alguma documentação do arquivo do Tribunal de Contas. Aparentemente, e segundo o então Conde de Oeiras, em meados do século XVIII, alguns contratos lançados no Conselho Ultramarino ficariam desertos, não aparecendo interessados. ${ }^{68} \mathrm{Uma}$ exposição posterior da contadoria geral aponta as recorrentes "desordens [...] nas arrematações que se faziam pelo Conselho Ultramarino nos contratos da América, sendo a maior parte delas feitas a homens a quem [se] chamavam testas de ferro e que de ordinário eram desconhecidos e faltos de abonação" ${ }^{\prime \prime 9}$. Esses dois motivos teriam sido suficientes para se retirar ao Conselho Ultramarino o direito a arrematar os contratos régios, tendo entretanto constituído mais uma demonstração do processo de degradação institucional vivida pelo Conselho Ultramarino.

Pela mesma altura, as Juntas da Fazenda experienciavam tempos de grande vitalidade administrativa, arrematando contratos a seu talante. Naturalmente, qualquer alteração a este quadro, mesmo que promovida pelo Erário, não seria bem recebida, e foi o que aconteceu quando no início da década de 1790 o presidente do Erário Régio, o visconde de Vila Nova da Cerveira, decidiu canalizar para Lisboa a decisão sobre aquela matéria. Por provisão de 23 de março de 1790, a Junta da Fazenda do Rio de Janeiro foi informada de que a arrematação dos contratos da Aguardente do Reino e Ilhas, da Aguardente da Terra, das Passagens do Rio Paraíba e Paraibuna, dos Dízimos da Ilha de Santa Catarina, dos escravos para as Minas e dos Quintos dos couros do Rio Grande de São Pedro

68Provisão de 29 de agosto de 1769. TC, ER, n. 4.055, fls. 115-116.

${ }^{69}$ Exposição da Contadoria Geral, de 22 de dezembro de 1794. Idem, n. 4.044, fls. $142-157$. 
se passariam a fazer na corte (embora não entrasse em detalhes quanto à nova localização). ${ }^{70}$ Dois anos depois, as instruções de Cerveira foram um pouco mais longe, e a Junta do Rio de Janeiro recebeu ordens para apenas arrematar contratos de valor inferior a 10 milhões de réis por triênio. ${ }^{71}$

Conscientes do que seria uma evidente restrição à sua autonomia e, mais importante, à sua capacidade de gerir interesses locais, os membros da Junta do Rio de Janeiro reagiram, levantando, de imediato, obstáculos às orientações recebidas de Lisboa. Por um lado, adotaram uma estratégia dilatória, protelando o envio dos traslados das condições das arrematações anteriores que o Erário tinha, entretanto, requisitado. Na prática, essa medida deixava o Erário Régio na ignorância, sem saber exatamente quais eram os termos de negociação tradicionais, o que o tornava mais propenso a subavaliar os rendimentos em causa. ${ }^{72}$ Por outro lado, e perante o escândalo, quer do contador-mor Luís José de Brito, quer do presidente do Erário, o agora marquês de Ponte de Lima, a Junta fluminense optou por desobedecer abertamente, continuando a arrematar os contratos que lhe haviam sido retirados (o de Escravos para Minas, o das passagens dos rios Paraíba e Paraibuna e dos registos de Viamão e Santa Vitória $^{73}$ ). Por último, procurou influenciar o príncipe regente, elencando uma lista de inconvenientes que decorriam da transferência do centro de decisão em matéria de arrematações. Questionaram, em particular, os métodos de arrematação (por lanços particulares sem que os lançadores se conhecessem) e mesmo os próprios resultados financeiros obtidos. A exposição defensiva, em jeito de réplica, que se fez no Erário sobre as vantagens alcançadas com a nova localização confirma a repercussão das queixas. Confirma também o alcance e o sucesso da resistência oferecida pela administração periférica.

Não deixa de ser surpreendente que na última década de Setecentos emergisse um conflito institucional com estes contornos e dimensões entre um dos principais espaços de poder do reino (o Erário Régio) e um representante da administração periférica da coroa (a Junta do Rio de Janeiro), que, além do mais, lhe deveria ser subordinado. Ainda mais surpreendente é o fato do primeiro se ter visto na necessidade de explicar as vantagens das opções que tomava. ${ }^{74}$

\section{Recursos financeiros para a guerra}

Outra reação explícita à diligente observância das ordens emanadas pelo Erário encontra-se na delicada gestão dos recursos financeiros para a guerra; assunto que Lisboa tinha, por tradição, grandes dificuldades em controlar.

Com a intensificação do conflito com os espanhóis no Brasil meridional, entre os anos de 1774 e 1777, e com a inevitável mobilização de tropas, o marquês de

\footnotetext{
70Provisão de 23 de março de 1790. TC, ER, n. 4.056, fl. 195.

${ }^{71}$ Provisão de 10 de março de 1792. Ibidem, fl. 257.

${ }^{72}$ Provisão do Visconde de Vila Nova da Cerveira, de 4 de setembro de 1793. Ibidem, fl. 290.

${ }^{73}$ Provisão para o corpo da Junta, de 1 de março de 1794. Ibidem, fl. 299. Provisão para o escrivão da Junta, de 28 de março de 1794. Ibidem, fl. 301.

${ }^{74}$ Exposição da Contadoria Geral, de 22 de dezembro de 1794. Idem, n. 4.044, fls. 142-157.
} 
Pombal autorizou a Junta da Fazenda do Rio de Janeiro a gastar "todo o dinheiro quanto preciso for". O montante disponibilizado dizia respeito aos rendimentos dos subsídios voluntário e literário e às remessas feitas pela Junta da Fazenda de Angola. As mesmas instruções deixavam muito clara a proibição de recorrer aos rendimentos dos reais Quintos, que deveriam continuar a ser remetidos para o reino. ${ }^{75}$

No entanto, os muitos compromissos decorrentes da pressão colocada por Ceballos em Santa Catarina e no Rio Grande do Sul levaram Lavradio a socorrer-se dos Quintos, desobedecendo, assim, às ordens de Carvalho e Melo. Ainda que perdoado, Lavradio foi repreendido, via Erário Régio, e informado para não voltar a praticar "semelhante extração contra as positivas ordens que jamais permitiram que esta consignação se distribuísse nessa capitania por qualquer urgente motivo que ocorresse".76

Importa sublinhar que tal desobediência, isto é, lançar mão dos "sacrossantos" Quintos, voltaria a repetir-se, para grande desagrado de Lisboa. Aproximadamente 20 anos depois (1797-1798), a mesma Junta, agora presidida pelo conde de Resende, resolveu reter os Quintos como forma de suportar os gastos inusitados da frota de vários navios de guerra atracada no Rio de Janeiro. No Erário, depressa se censurou aquela opção. Numa longa exposição, o contador-geral referiu que perante as verbas que na altura a Junta administrava não havia razão para se ter retido os Quintos, sobretudo quando o reino se via na iminência de uma invasão franco-espanhola. Acusando a Junta de falta de cuidado na administração das "rendas reais" e de má "economia nas suas despesas", o contador-geral parecia recomendar a imposição de restrições à autonomia daquela instância. Referiu então que as

Deliberações da Junta combinadas com as circunstâncias do tempo em que elas se tomaram dependem de uma grande providência, que a acautele para o futuro os inconvenientes que podem resultar [...] se continuarem as despesas que lhe encarregaram e que servem de pretexto para absorver a Junta todos os cabedais que chegue a entrar nos cofres como a este Real Erário pela falta das remessas que para ele se devem fazer. ${ }^{77}$

A especificidade do incumprimento reiterado, que deu o mote à exposição do contador-geral, prende-se, sobretudo, com a dificuldade de compatibilizar a jurisdição do Vice-rei com as prescrições do Erário em assuntos político-militares. Porém, a mesma exposição exorbita aquela circunstância particular, na medida em que se aconselha uma "grande providência" no sentido de retirar às Juntas da Fazenda a autonomia que elas teriam, entretanto, alcançado.

Cumpre notar que a resistência montada pela Junta da Fazenda fluminense às diretrizes emanadas pelo Erário, ainda que remetesse para um quadro de autonomia estrutural que alguns julgavam excessiva, nem sempre era resultado

\footnotetext{
${ }^{75}$ Dauril Alden, Royal government in Colonial Brazil, with special reference to the administration of the Marquis of Lavradio, Viceroy, 1769-77, Los Angeles, University of California Press, 1968, p. 322-323.

${ }^{76}$ Provisão do Marquês de Angeja, de 24 de setembro de 1778. TC, ER, n. 4.055, fls. 410-413.

${ }^{77}$ Exposição do Contador Geral, de 6 de maio de 1799. Idem, n. 4.044, fl. 167
} 
de um desrespeito ostensivo (decorrente da defesa da jurisdição que se julgava ameaçada). Por vezes, as circunstâncias tornavam impossível a boa cooperação institucional. A esse respeito, a pressão colocada pelos custos associados à proteção marítima do Brasil continuou a dificultar a desejada solidariedade administrativa entre o centro e a periferia. Custear o dispositivo naval que a Secretaria de Estado da Marinha enviava para o Brasil a partir de 1797 deixava a Junta do Rio de Janeiro e os seus presidentes com grandes dificuldades de tesouraria, impondo o recurso a rendimentos oficialmente interditados, fossem os Quintos ou outros quaisquer.

Assim aconteceu em setembro de 1801, quando o conde de Resende, perante as exigências financeiras do comandante da esquadra, Donald Campbell (40 milhões de réis), se viu forçado a socorrer-se dos fundos que a Mesa da Inspeção da cidade administrava autonomamente e que se deveriam expedir para Lisboa (tratava-se essencialmente do rendimento do Donativo). Justificou-se então com as ordens que o próprio Donald Campbell tinha recebido do príncipe regente, por via da Secretaria de Estado, que sublinhavam a necessidade de nada faltar aos navios de guerra que patrulhavam a costa brasileira.

\section{Para Carvalho e Melo, as Juntas da Fazenda ofereceriam outras garantias de lealdade, apesar da distância a que se encontravam de Lisboa}

O Vice-rei teve, contudo, grandes dificuldades para persuadir os deputados da Mesa da Inspeção, certamente receosos da reação do presidente do Erário Régio. Aceitaram depositar o dinheiro pretendido no cofre da tesouraria da Junta unicamente mediante a condição de o conde de Resende assumir a responsabilidade integral da operação, o que este fez. Com o tradicional dramatismo inscrito nesse tipo de correspondência, referiu "que tudo o que me pertence é de Sua Alteza Real e pelo seu serviço nunca tive nem terei a menor hesitação em derramar o meu sangue até à última gota".78

O cuidado colocado pelo Vice-rei no ofício que escreveu a D. Rodrigo de Sousa Coutinho revelou o desconforto inerente à sua posição. Enquanto Vice-rei, o conde de Resende era o principal responsável pela defesa do Brasil. Contudo, ao dar cumprimento a tal função, via-se obrigado a desrespeitar muitas das ordens que lhe eram transmitidas pelo presidente do Erário.

Em Lisboa e escrevendo também em setembro de 1801, D. Rodrigo de Sousa Coutinho veiculava o essencial dos argumentos apresentados pelo contador-geral, em 1799. No mesmo documento em que salientou a importância "de se conservar no Brasil uma grande esquadra que possa impedir qualquer golpe de mão de parte de um inimigo", o presidente do Erário associou sintomaticamente a resolução do problema financeiro colocado pela esquadra com o cumprimento das obrigações burocráticas da Junta da Fazenda. Referiu, então, "que nestas circunstâncias,

${ }^{78}$ Ofício do Vice-rei para D. Rodrigo de Sousa Coutinho, de 11 de setembro de 1801. AHU, Avulsos, Rio de Janeiro, cx. 194, doc. 22; cx. 191, doc. 89; cx. 185, doc. 110. 
Sua Alteza Real não dá por ora maiores e mais amplas providências porque também a Junta da Fazenda não tem mandado os Balanços da receita e despesa da capitania". Simultaneamente, advertiu o conde de Resende no sentido de este adotar uma gestão mais criteriosa dos recursos da capitania, canalizando-os maioritariamente para a defesa. O Vice-rei deveria procurar "evitar toda a Despesa inútil e fazer as competentes economias em tudo o que não for necessário para a conservação do Exército e da Marinha que seguram a defesa da Capitania". ${ }^{79}$

Nos primeiros anos do século XIX - 50 anos depois da entrada no governo de Sebastião de Carvalho e Melo e 40 anos depois do estabelecimento do Erário Régio -, era este o quadro que, em grande medida, pautava as relações entre uma das principais instâncias da administração central e um espaço que lhe estava formalmente submetido. Eram então indisfarçáveis os sinais de incumprimento, quando não de desobediência descarada, certamente incompatíveis com os planos originais de Carvalho e Melo.

\section{Conclusão}

Pela relevância que deteve, justifica-se, antes de mais nada, realçar o significado associado à constituição do Erário Régio para a generalidade do sistema político português dos Setecentos, quer ao nível da administração do reino, quer ao nível da administração do império. A subordinação financeira (com consequências administrativas e políticas) que se impôs à generalidade das repartições e tribunais pode e provavelmente deve ser vista como um dos mais importantes pilares da governação pombalina. Tratou-se de um claro sinal da natureza centralizadora da sua política que não terá tido equivalente no quadro da reforma política e institucional. Repare-se que a Intendência-Geral da Polícia — outra das principais criações do período Josefino — tinha a sua ação geograficamente limitada.

Ao retirar às demais repartições do Estado a administração de consignações particulares, Pombal não só restringiu autonomias e jurisdições, como fez canalizar para o Erário parte substancial da decisão política sobre matérias antes dispersas e, até certo ponto, corporativamente defendidas. Tudo ou quase tudo que dissesse respeito à arrecadação de receitas e pagamentos ficou sob a vigilância atenta do Erário. Tratou-se, portanto, de fazer convergir - centralizar - o que antes se encontrava disseminado pelo restante sistema político metropolitano. Para além disso, promoveu (ou contribuiu para promover) uma notável concentração de poder na pessoa de Carvalho e Melo, que, de forma significativa, assumiu a chefia do Erário, atitude que, como se notou anteriormente, parece denunciar que os modelos norteadores da ação política de Pombal não se ficavam por França ou Espanha. Nesse caso, a inspiração terá tido um cariz essencialmente britânico. Dificilmente passaria despercebido a Carvalho e Melo, enquanto serviu como embaixador em Londres, que o ascendente de Walpole tinha muito a ver com a margem de manobra que lhe garantia o exercício do cargo de First Lord of the Treasury (na Grã-Bretanha,

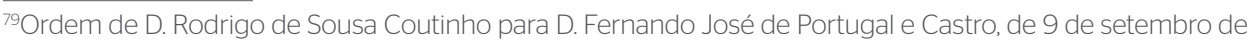
1801. AHU, Avulsos, Rio de Janeiro, cx. 194, doc. 49. 
diretamente ligado ao cargo de primeiro-ministro). Tratava-se, portanto, de replicar uma fórmula comprovadamente bem-sucedida.

Essa tendência centralizadora foi transposta para as conquistas, em especial, para o Brasil, tendo-se procurado impor um circuito integrado e estruturalmente hierarquizado entre o Erário e as Juntas da Fazenda. As rotinas de governo promovidas por Pombal, e que se procuraram revisitar, denunciam uma certa consonância entre "as ambições do legislador" e "os resultados", pelo menos num primeiro momento. A subordinação de partida terá sido inclusivamente reforçada por um conjunto de outras medidas de cariz menos sistematizado, como foi o caso das alterações promovidas na composição das Juntas (incorporando elementos da absoluta confiança do ministro de D. José I).

Os sinais de aparente sentido contrário, por seu turno, constituíram fenômenos circunscritos, ilustrativos de um certo refinamento institucional ou racionalização administrativa que a jusante implicavam a delegação de competências para o exercício de uma determinada função, mas que não colocavam em causa o sentido da política colonial pombalina.

Isso não significa que o caminho da centralização tivesse avançado sem sobressaltos. Muito pelo contrário. Os problemas relacionados com as arrematações de contratos e com a gestão de recursos para a guerra fizeram emergir uma dinâmica de oposição às ordens emanadas pelo Erário Régio, tendo-o mesmo levado a assumir uma posição defensiva e a justificar as opções que tomava. Na verdade, as dificuldades colocadas à administração central no final do século XVIII, em especial a insubordinação institucional que aqui se detectou, insinuam a persistência de um quadro de resistência que não era propriamente novo, mas que ganhara contornos institucionais inéditos.

$O$ fato de essa resistência se encontrar essencialmente concentrada na última década dos Setecentos torna muito tentador explicá-la à luz do fim da maior rigidez do "consulado" pombalino. Isso não é dizer que a sua reforma tenha sido abandonada. Os governos subsequentes, formados durante a Viradeira, conservaram os fundamentos essenciais da administração de Carvalho e Melo, em que se incluiu naturalmente o Erário Régio e o sistema de Juntas da Fazenda. É, contudo, legítimo associar a falta de eficácia verificada com a eventual sedimentação do poder da Junta do Rio de Janeiro, que, com o passar do tempo, se libertou da subordinação formal, o que foi certamente aproveitado por elites locais agora mais acomodadas aos termos de funcionamento daquele tribunal. Adicionalmente, deve-se acrescentar que as fragilidades reveladas pelo centro político da monarquia, incapaz de exercer autoridade de forma mais resoluta, ter-se-ão agudizado durante os primeiros anos da regência de D. João VI, período que ficou marcado pela discórdia cortesã e pela disputa política. ${ }^{80}$

\footnotetext{
${ }^{80} \mathrm{~A}$ esse respeito, ver, por exemplo, Valentim Alexandre, Sentidos do império - questão nacional e questão colonial na crise do Antigo Regime português, Porto, Afrontamento, 1993, p. 116-140, e Jorge Pedreira; Fernando Dores Costa, D. João VI: o Clemente, Lisboa, Círculo de Leitores, 2006, p. 65-83; 86-95.
} 